Bondarenko Natalia,

$\mathrm{PhD}$ in Law, Associate Professor, Kyiv National University of Trade and Economics, 19, Kyoto str., Kyiv, 02156, Ukraine ORCID: 0000-0001-9370-301X

Researcher ID: M-6307-2016

\title{
WOMEN IN THE SYSTEM OF PARLIAMENTARISM AS A COMPONENT OF A DEMOCRATIC STATESUMMARY
}

The article analyzes the parliamentary experience of women's activities in Ukraine and countries at different stages of their development. National legislation on gender equality has been examined, taking into account international standards. The degree of political activity of Ukrainian womanhood in comparison with international parliamentary practice is determined and the conclusions are made taking into account the positive achievements of women's activity in world parliamentarism.

Keywords: women's suffrage, Verkhovna Radaof Ukraine, democracy, parliamentarism.

Бондаренко Наталія. Жінки в системі парламентаризму як складова демократичної держави.

У статті проаналізовано парламентський досвід діяльності жінок в Україні та країнах на різних етапах їх розвитку. Національне законодавство про гендерну рівність було вивчено з урахуванням міжнародних стандартів. Визначено ступінь політичної активності жіночої статі України порівняно з міжнародною парламентською практикою та зроблено висновки з урахуванням позитивних досягнень жіночої активності у світовому парламентаризмі.

Ключові слова: виборче право жінок, Верховна Рада України, демократія, парламентаризм.

Today, politics is becoming more and more professional and an extremely important field of activity to which more and more women are involved. The latter choose this type of activity because they have the right education, skills, ambitions and desires. In the XX-XXI centuries in different continents, in countries with different traditions, history, women became prominent in politics and achieved the highest positions of women leaders: Indira Gandhi, Golda Meir, Corazon Aquino, Margaret Thatcher, Binazir Bhutto, Angela Merkel. 
Insufficient representation of women in government bodies gives rise to doubts about the effectiveness of the respective political structures and the democracy of the state system of this country, which determined the actual direction of our research.

Various aspects of the position of women in Ukrainian politics have been studied by the following scholars: I. Grabovskaya, L. Kormich, and E. Hansova (2), T. Martseniuk (3), T. Slabchuk (4), and L. Pylyaeva (5). Radish J. and Kozuhar O. (6) and the like. The analysis of Ukrainian gender equality policy in all spheres of life at the present stage has set one of the main tasks - determining the place of women in the parliamentary system in the conditions of building a democratic state.

Formulation of the problem. For 100 years, women have been fighting for their political rights, which envisage active participation in the administrative process with the right to vote and to be elected to power. Finland was the first country to grant women political rights: in 1906, women were given the right to vote, and in 1907, 10\% of women represented the national parliament. The same percentage of women's representation in the European Parliaments was achieved only after the Second World War: in Sweden in 1953, in Denmark in 1966, in Norway in 1973 (Pilyaeva L., 2010, p. 503).

An important aspect of this issue was that the newest constitutions of states enshrined the principle of equality of citizens, including in the electoral process, regardless of gender, race and political views. However, in most countries, there is no de facto equality in the representation of women in parliament. For example, according to the International Parliamentary Union, as of 2018, women on average in the world occupied only $23 \%$ of seats in national parliaments. The Verkhovna Rada of Ukraine of the 8th convocation comprised $12 \%$ of women, so Ukraine ranked 144th in 193 countries (Martseniuk T., 2018, p. 43).

The experience of European countries and the USA shows that the participation of women in the work of parliaments and other representative institutions is extremely important and effective for society as a whole, because they focus on health, education of children, education, social protection of the population etc.

Today, from $37 \%$ to $45 \%$ of parliamentarians in Denmark, Finland, Norway, Sweden are women. Sweden is the leader among these countries, with $45 \%$ of women in parliament (Radish J., 2015, p. 117). Analyzing the regional aspect of this topic, it should be noted that on the American continent, the percentage of women parliamentarians $-22 \%$, in European countries (not including Scandinavian) $-20 \%$, countries in Asia and Africa (Sahara region) - 18\%, Pacific countries - $15 \%$, Arab countries - 10\% (Pilyaeva L., 2010, 505).

The key to high representation of women in Northern politics is the introduction of a proportional electoral system that is internationally recognized as more democratic, one that adequately represents the entire spectrum of political forces in 
society and the distribution of sympathies with the electorate. Equally important is the socio-economic factor: women's representation is usually higher in countries with high levels of employment and education, where public relations allow women to combine family responsibilities and work or other social activities. In these countries, considerable attention is paid to the development and improvement of collective action by women's organizations within and outside political parties, leading to increased participation of women in politics.

In the following we will analyze the Ukrainian legislation and statistics on equality of rights of women and men.

After the collapse of the USSR and the transition to an independent state Ukraine, there was a collapse in the economic, political and social spheres. During this period women were disturbed from active participation in the political process. Subsequent state-building processes led to the legislative regulation of gender equality, but gender stereotypes continued to live in society and consciousness role-sharing types, and thus the woman has only slowly entered the field of politics.

The legal position of a woman in society is determined by the concept of her legal status, which consists of a set of rights, duties and legal guarantees of a person (Slabchuk T., 2010, p. 181). The basic legislative act defining the status of a woman became the Constitution of Ukraine, in article 24 which states: «... Equality of rights of women and men is ensured by: providing women with equal opportunities in social and political and cultural activity, in obtaining education and vocational training, in work and the reward for it...» (7).

On September 8, 2005, the Law of Ukraine «On equal rights and opportunities for women and men» was adopted, which defined such basic concepts as equal rights and opportunities for women and men, gender discrimination, affirmative action, etc. Article 3 of the Law states that «The state policy on equal rights and opportunities for women and men is aimed at promoting gender equality; non-discrimination based on sex; application of positive actions; ensuring equal participation of women and men in socially important decisions; ensuring equal opportunities for women and men in combining professional and family responsibilities»(8). Section II of the Law identifies government and institutions that are empowered to ensure equal rights and opportunities for women and men. These include, first of all, the Verkhovna Rada of Ukraine, authorized Verkhovna Rada of Ukraine on Human Rights, the Cabinet of Ministers of Ukraine. In particular, article 8 of the Law lists the following powers of the Verkhovna Rada of Ukraine:

- defining the basic principles of gender policy of the state;

- implementation of the principle of equal rights and opportunities for women and men in legislation;

- exercising parliamentary control over the implementation of legislative acts on these issues. 
This law is not devoid of disadvantages in its mechanisms for implementing gender equality policy, to which T. Martseniuk rightly pointed out, pointing to the declarative nature of the document in the absence of legal responsibility for violation of its norms (Martseniuk T., 2018, p.45).

Ukraine has also made a low international commitment to equal rights and opportunities for women and men. Thus, in 1980, the Ukrainian Soviet Socialist Republic ratified the UN Convention on the elimination of all forms of discrimination against women and the optional Protocol thereto, which became part of national law (9). Ukraine has committed itself every four years to report to the Convention Committee on the fulfillment of its obligations. Article 7 of the Convention states that «States Parties shall take all appropriate measures to eliminate discrimination against women in the political and social life of the country and, in particular, shall ensure that women, on equal terms with men, have the right:... to participate in the formulation and implementation of government policy. and hold public office and perform all public functions at all levels of government».

In accordance with the Millennium Development Goals, which were set by the UN Millennium Summit in 2000 and made binding by 2015, Ukraine has identified the goal of «gender equality» (10). Under this objective Task № 1 wasby 2015 «to ensure a gender ratio of at least 30 to 70 genders in representative authorities and higher levels of executive power». As you can see, Ukraine has not met this goal, because in the last parliamentary elections on July 21, 2019, 86 women deputies were elected to the Verkhovna Rada of Ukraine, which is $20 \%$ of its membership. Therefore, de jure Ukrainian women have been accorded equal status with men, and de facto, it is worth monitoring this process, because legislative recognition and harmonization of national legislation with the requirements of European law is only the first step towards solving a problem that requires the proper implementation of these acts.

The level of representation of women's participation in government characterizes their role in the political life of the country. According to I. Grabovskaya, the most striking indicator of the formation of a gender equality society is the quantitative and qualitative indicators of women's participation in the political process and their presence in the power structures of the state up to the highest level $(1,10)$. That is why we characterize the political activity of women in the Verkhovna Rada of Ukraine from 1990 to 2019, as it is the highest representative authority with the exclusive right to make laws and to be a model of the idea of equal rights and opportunities for women and men. According to experts, women working in the Verkhovna Rada of Ukraine face vertical and horizontal segregation and gender stereotypes (Martseniuk T., 2018, p. 43).

The development of an independent state, the processes of democratization of society did not improve the situation regarding the proportional representation of both 
gems in the parliament of Ukraine. Thus, in 1990 only 3\% of women were admitted to the Verkhovna Rada of Ukraine; in $1994-5,7 \%$ in $1998-8,1 \%$, in $2002-5,1 \%$, in $2006-8,5 \%$, in early elections in $2007-7,6 \%$, in $2012-10,2 \%$, in $2014-12,3 \%$, in $2019-19,1 \%$. The total percentage is $8,84 \%$. Today we can argue the fact that the level of women's representation in the Ukrainian Parliament has improved overall, however, remains unsatisfactory. This situation is not in line with the UN Millennium Development Goals, in which Ukraine has taken the obligation to increase women's representation in parliament by up to thirty percent.

The percentage of Ukrainian women's participation in parliamentary activity compared to developed democracies remains low and requires new mechanisms for overcoming gender imbalance.

The struggle for women's rights for equal rights has led to the emergence of a concept of parity democracy based on the postulates: development of tolerance in society, gender education, prevention of violence against women, development of political culture of subjects of law. Therefore, the main thesis of the concept is that men and women have equal civic dignity (Slabchuk T., 2010, p. 184).

Political experience assures that the country will develop more stably if women are represented in the power structures at the level of $30-40 \%$. The most successful international practices include the establishment of a gender-based parliament through the application of: 1) positive action to implement gender quotas; 2) establishment of state institutions for monitoring the observance of equality between women and men; 3) implementation of the gender examination of bills.

Most countries with significant representation of women in the upper echelons of government use positive discrimination, i.e. the introduction of quotas in the field of electoral law. They are used as an exceptional temporary measure when, due to religious characteristics, persistent stereotypes in society, women are not able to exercise their rights on an equal basis with men, even if they are envisaged by legislation.

In Sweden, since 1994, political parties that go to the election have to include an equal number of men and women in their electoral lists, which is why the government of this country is now represented by $50 \%$ by women. In Norway, the quota law applies to women's participation in both political and public organizations and corporate governance. The legislation of France for the political parties participating in the elections stipulates a norm according to which no more than $50 \%$ of persons of the same gender should be included in the party list (Radish J., 2015, p. 117).

Generalizing international experience, we can conclude that the introduction of electoral quotas can be done in two ways: at the legislative level, when, according 
to the regulations of the state, political parties are obliged to include a percentage of women in their list. The law may also provide for certain preferences in respect of women's quotas when drawing up party lists in the form of additional state funding, or the application of sanctions (reduced funding, refusal of registration) in case of their inappropriateness. Belgium, Greece, Italy, France resorted to this method of gender equality. However, there are sympathizers and opponents of such a quota policy among politicians and lawyers. The latter believe that such a policy contravenes the principles of democracy, gender equality, narrows voter opportunities, and parties themselves resort to the impossibility of the voters of their candidates (Pilyaeva L., 2010, p. 506).

In most EU countries, the issue of quotas is addressed directly by political parties, because under such condition's parties have the opportunity to demonstrate to voters their attitude to the issue of equal rights and opportunities for women and men, and the principle of equality is not violated. Gender quotas are more commonly used by parties in the humanist (greens) or social-democratic directions, as evidenced by the experience of countries such as Austria, Argentina, Brazil, the United Kingdom, Greece, Denmark, Ireland, Spain, Luxembourg, Portugal, Hungary, Sweden (Radish J., 2015, p. 117).

In some countries, individual state institutions are being set up to counteract the inequality of gender in order to control the equality of women and men. Thus, in Greece created the post of the Secretary of State on Equality, in Finland the Ombudsman's position on equality was introduced and the Council on Equal Rights Range Council, the Ministry of Equality in Portugal is considering this area. In such circumstances, the content of the policy, the political culture and the behaviour of the subjects of law change towards each other.

It is also advisable to carry out gender examination of bills. Thus, the new gender indicator of the Verkhovna Rada of Ukraine activities is based on the Action Plan of action for gender sensitive parliaments of the Inter-Parliamentary Union, which has the following components:

- increasing the number of women in parliament;

- improvement of legislation and policy of gender equality in the activities of the parliament;

- enhancing parliamentary culture;

- gender mainstreaming in all parliamentary activities;

- the distribution of responsibility for gender equality between women and men deputies;

- encouraging political parties to implement gender equality policies;

- gender sensitivity and equality of staff parliament (Martseniuk T., 2018, p. 51). 
American researchers have come to the conclusion that women are the most effective lawmakers. For example, in the United States between 1984 and 2004, women received $\$ 49$ million more per year for their regions than their colleagues of men. Women's deputies of parliament are up to 3 more laws in Congress and support an average of 26 more laws than men, and more sponsors. All bills introduced between 1981 and 2009, which were drafted by women, have moved further in the legislative process, attracted more attention from the press, and are generally considered more meaningful (Radish J., 2015, p. 118).

Based on the above, we consider it appropriate to propose measures that, in our opinion, can enhance the status of Ukrainian women in politics: to further monitor national legislation and its adaptation to international and European standards on combating discrimination against women and eliminating domestic violence; implement national mechanisms to ensure women's representation in government at all levels, in line with the UN Millennium Development Goals; create the necessary socio-economic conditions for women's political activity; to promote the political culture of the population of Ukraine in order to overcome gender stereotypes.

\section{Conclusion.}

1) The civilized world has long ago understood and accepted the need for active participation of women in state-building, as their presence changes politics into socially oriented programs, the ideals of humanism and non-violence. The active participation of women in political life is closely linked to the economic development and democratic foundations of society. Proof of this is the UN indicators, which show that the Scandinavian countries occupy the first positions in women's power representation, leading in terms of quality of life and economic development.

2) Formally, Ukraine has legally enshrined the basics of gender equality in society, including at the level of international standards. However, as the results of the gender analysis of the Verkhovna Rada of Ukraine have shown, the situation of women's participation in political governance remains unsatisfactory, including through the low level of representation of women in the Verkhovna Rada of Ukraine, and even the last elections since July 21, 2019, which took place on a democratic basis, contributed to some gender change but did not increase women's representation to $30 \%$.

3) An objective need has emerged in Ukrainian society to change the patriarchal type of political culture, to remove obstacles to women's entry into politics, because this is the way to democracy and the establishment of civil society. 


\section{REFERENCES}

1. Grabovska I. Women in the political elite of Ukraine. Women's world. 2004. № 4.3 (19). P. 9-11

2. Kormich L., Gansova E. Legal status of women in Ukraine. Actual problems of the state and law. 2004. Will 22. P. 397-402.

3. MartseniukT. Women in «big politics»: gender analysis of the Verkhovna Rada of Ukraine. Scientific notes NaUKMA. Sociology. 2018. T.1. C. 43-53. URL: http://nbuv.gov.ua/UJRN/NaUKMAs_2018_1_6. (accessed on: 08/19/2019).

4. Slabchuk T. Determination of the status of women in Ukrainian politics at the end of XX - beginning of XXI century. Intelligentsia and power. 2010. Will 20. P. 180-186. URL: http://nbuv.gov.ua/UJRN/iiv_2010_20_21.

5. Pilyaeva L. Participation of women in politics: international experience and Ukrainian realities. Collection of scientific works. Gilea: Bulletin of the Kyiv Academy of Sciences, Kyiv. 2010. P. 502-509.

6. Radish J. The role of women in public administration: foreign experience (based on literature). Investments: practice and experience. 2015. № 15. P. 113-118. URL: http://nbuv.gov.ua/UJRN/ipd_2015_15_27(access date: 08/19/2019).

7. The Constitution of Ukraine of 28.06.1996. URL: https://zakon.rada. gov.ua/laws/show/254k/96-vp.

8. The Law of Ukraine «On equal rights and opportunities for women and men» of September 8, 2005 No. 2866-IV URL: https://zakon.rada.gov.ua/laws/show/2866-15

9. The 1979 UN Convention on the elimination of all forms of discrimination against women. URL: https://zakon.rada.gov.ua/laws/show/995_207

10. UN Millennium Development Goals. Ukraine 2015. Goal № 6 «Gender Equality»: URL: http://www/ukraina2015.org.ua/tsil6 